\title{
Nipew New Disease Reports \\ First reports of Cryptostroma corticale causing sooty bark disease in Acer sp. in Canton Geneva, Switzerland
}

\author{
B. Cochard, J. Crovadore, P.Y. Bovigny, R. Chablais and F. Lefort*
}

Plants and Pathogens Group, Institute Earth Nature and Landscape, University of Applied Sciences Western Switzerland, 150 route de Presinge, 1254 Jussy, Switzerland

*E-mail: francois.lefort@hesge.ch

Received: 25 Nov 2014. Published: 08 Mar 2015. Keywords: Maple bark stripper's disease, extrinsic allergic alveolitis, fungal plant disease

\begin{abstract}
In June 2014, characteristic symptoms of sooty bark disease were observed on the trunk of an approximately 40-year-old maple tree in Canton Geneva, Switzerland. Five other nearby maple trees of identical age displayed similar symptoms on several branches but not on the trunk. Symptoms consisted of bark blistering and shedding, with long and broad black stripes, resulting in thick layers of fungal spores forming blackish stains under the bark (Fig. 1). Samples were taken from the dark stains and by coring into the trunk with an increment borer at $1.5 \mathrm{~m}$ height. Samples were seeded onto potato glucose agar (PGA) with ampicillin, from which pure fungal cultures were isolated and DNA extracted according to Lefort \& Douglas (1999). Subsequent PCR amplifications targeted the rDNA ITS region using the primer pair ITS4/ITS5 (White et al., 1991). DNA sequences were registered in the Nucleotide NCBI database (GenBank Accession Nos. KP114070-KP114098) and BLAST comparison provided a genetic identification for each isolate.
\end{abstract}

The core cut in 16 equal pieces, $1 \mathrm{~cm}$ long, yielded 16 isolates of Cryptostroma corticale only. Bark yielded 53 isolates from 30 samples that resolved into 20 different fungal species (Fig. 2). Cryptostroma corticale amounted to $23 \%$ of total isolates while the yield of Cytospora chrysosperma, a common canker agent of Populus spp. was 15\% of total isolates. Plant pathogens often observed in decaying trees, such as Dothiorella iberica, Mucor spp., Phomopsis spp. and Fusarium sp. yielded another 25\% altogether. Cryptostroma corticale was present in symptomatic bark and was the only microorganism retrieved from cores taken from the internal wood. After felling the tree, its cross section displayed an irregular yellow brown stain, with greenish margins, as often observed in diebacks caused by $C$. corticale (Fig. 3). This fungus is not only known as a pathogen of Acer spp., Tillia spp and Betula spp., but also as the agent of Maple bark stripper's disease, a hypersensivity pneumonitis, caused by its hyper allergenic spores (Emmanuel et al., 1966). This pathogen is considered established in the UK, France and Germany and was recently found in the Netherlands (Anonymous, 2014). This is the first report of an isolated and identified strain in Switzerland. This strain, labelled as UASWS1256 in our collection, has been deposited in the collection DSMZ-Deutsche Sammlung von Mikroorganismen und Zellkulturen (Braunschweig, Germany) under the reference number DSM 100040.

\section{Acknowledgements}

We are grateful to the State Directorate for Nature and Landscape, Geneva for funding this work.

\section{References}

Anonymous, 2014. Quick scan number: QS. Myc 417, 17 April 2014.

National Plant Protection Organization, the Netherlands. https://www.nvwa.nl/txmpub/files/?p_file_id=2206322

Emanuel DA, Wenzel FJ, Lawton, BR, 1966. Pneumonitis due to Cryptostroma corticale (Maple-Bark Disease). New England Journal of Medicine 274, 1413-1418.

http://dx.doi.org/10.1056/NEJM196606232742504

Lefort F, Douglas GC, 1999. An efficient micro-method of DNA isolation from mature leaves of four hardwood tree species Acer, Fraxinus, Prunus and Quercus. Annals of Forest Science 56, 259-263. http://dx.doi.org/10.1051/forest:19990308

White TJ, Bruns T, Lee S, Taylor J, 1990. Amplification and direct sequencing of fungal ribosomal genes for phylogenetics. In: Innis MA Gelfand DH, Shinsky J, White TJ, eds. PCR protocols. A guide to methods and applications. San Diego, CA, USA: Academic Press, 315-322.
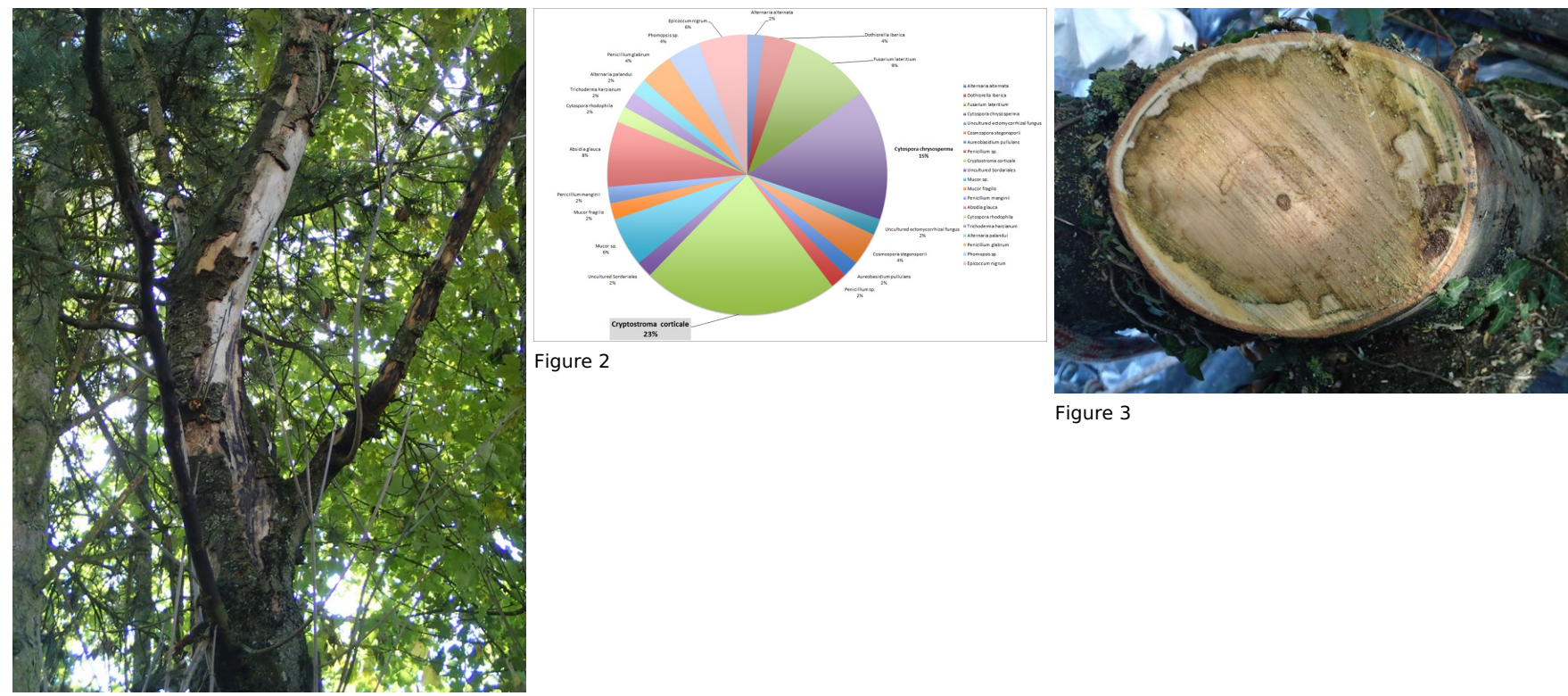

Figure 3

Figure 1

To cite this report: Cochard B, Crovadore J, Bovigny PY, Chablais R, Lefort F, 2015. First reports of Cryptostroma corticale causing sooty bark disease in Acer sp. in Canton Geneva, Switzerland. New Disease Reports 31, 8. http://dx.doi.org/10.5197/j.2044-0588.2015.031.008 (c) 2015 The Authors This report was published on-line at www.ndrs.org. uk where high quality versions of the figures can be found. 